\title{
Zooplankton community from restored peridunal ponds in the Mediterranean region (L'Albufera Natural Park, Valencia, Spain)
}

\author{
María Antón-Pardo* and Xavier Armengol
}

Department of Microbiology and Ecology. Institut Cavanilles de Biodiversitat i Biologia Evolutiva. University of Valencia, Dr. Moliner, 50, 46100 Burjassot, Valencia, Spain.

* Corresponding author: anparma@uv.es

Received: 29/2/09 Accepted: 30/8/09

\begin{abstract}
Zooplankton community from restored peridunal ponds in the Mediterranean region (L'Albufera Natural Park, Valencia, Spain)

The zooplankton of eight restored peridunal ponds located in L'Albufera Natural Park (Valencia, Spain) was sampled fortnightly from November 2006 to July 2007 to study the effect of hydroperiod, restoration and other environmental variables in the zooplankton community structure. Ponds with different hydroperiods were selected: two permanent ponds, two temporary ponds with a long hydroperiod ( $>6$ months a year) and four temporary ponds with short hydroperiod ( $<6$ months). The time since they were restored was also different: two of them were only modified; some were restored in the 1990s, and others were regenerated in recent years (2004-05). The results showed great heterogeneity in the zooplankton community, most probably due to the strong differences in some limnological variables (mainly conductivity and depth). The dominant group, in terms of density, were the copepods in four ponds, mainly because the high densities of nauplii and copepodites; the rotifers in three; and cladocerans only in one pond. However, the rotifers presented the highest cumulative richness in all the systems. Species richness in the permanent ponds was higher than in the temporary ones. The main environmental variables affecting the community composition were depth, highly related to permanence of water, restoration time and conductivity.
\end{abstract}

Key words: Hydroperiod, peridunal ponds, species richness, zooplankton.

\section{RESUMEN}

Comunidad zooplanctónica en charcas peridunares mediterráneas restauradas (Parc Natural de l'Albufera, Valencia, España)

El zooplancton de ocho charcas peridunares del Parque Natural de L'Albufera (Valencia, España) se siguió quincenalmente desde Noviembre 2006 a Julio 2007 para conocer el efecto del hidroperiodo, de la restauración y de otras variables ambientales en la estructura de la comunidad zooplanctónica. Se estudiaron dos charcas permanentes; dos temporales con hidroperiodo largo (> 6 meses al año); y cuatro con hidroperiodo corto ( $<6$ meses). También diferían en el año en que fueron restauradas: dos de ellas existían previamente y fueron parcialmente modificadas, algunas fueron restauradas en los 90's, y otras fueron regeneradas más recientemente (2004-05). Los resultados muestran una gran heterogeneidad en la comunidad de zooplancton debido probablemente a las grandes diferencias en las variables limnológicas, principalmente la profundidad y conductividad. El grupo dominante (en densidad) fueron los copépodos en cuatro de los sistemas, debido a la alta densidad de los nauplios y copepoditos, los rotíferos en tres charcas, y los cladóceros solo en una. Pero en todas las charcas, los rotíferos presentaron la mayor riqueza acumulada. Las principales variables ambientales en la composición de la comunidad fueron la profundidad, muy relacionada con la permanencia del agua, la restauración y la conductividad, ya que en las charcas permanentes la riqueza específica fue mayor que en las temporales.

Palabras clave: Hidroperiodo, charcas peridunares, rotíferos, riqueza de especies, zooplancton. 


\section{INTRODUCTION}

In the Mediterranean region, limnological studies have shown the great biodiversity of their aquatic systems (Quintana et al., 2006; Céréghino et al., 2008). The wide array of ecological factors (depth, hydroperiod, macrophytes, productivity and salinity) that can be found in them (Beklioglu et al., 2007) could explain this fact, by promoting a high environmental heterogeneity. In this region, temporary ponds are very important for aquatic organisms, due to the scarcity of permanent water bodies. A relevant factor influencing their aquatic community is the duration of the wet phase (or hydroperiod). Inhabitants of these ponds must have adaptations such as rapid lifecycles, diapausing eggs or resting stages (Wellborn et al., 1996; Williams, 2000) to ensure the survival in the dry phase. The structure of zooplankton communites can be influenced by several biotic and abiotic factors. Different studies have suggested the relative importance of some environmental variables such as: morphometry, flooded surface, duration of hydroperiod, trophic status, salinity and vegetation cover (e.g. Armengol \& Miracle, 1999; Boix et al., 2001, Oertli et al., 2002, Eitam et al., 2004, Green et al., 2005, Frisch et al., 2006). Only a few of these studies include rotifers, even though they usually represent the major fraction of zooplankton species ri- chness (e.g. Fahd et al., 2000; Ortega-Mayagoitia et al., 2000; Serrano \& Fahd, 2005).

In the Valencian Community (Eastern Spain) some of the temporary ponds are peridunal ponds located in coastal areas. The coastal temporary ponds are considered ecoystems with high species richness (López et al. 1991; Mazuelos et al. 1993; Boix et al., 2007), although some of their aquatic fauna is still unknown and poorly studied (Boix et al., 2001). In L'Albufera Natural Park, there are many peridunal ponds, where only few studies have been carried out (Soria \& Alfonso 1993; Alfonso, 1996; Rueda-Sevilla et al., 2006). In the 1960s most of these systems were heavily altered by humans, but in the last twenty years some of them have been restored. These ponds are adequate systems to study the influence of natural processes and anthropogenic activities on the zooplankton community. The main aim of this study is to assess the zooplankton community composition in a selected group of these restored peridunal ponds, and to address the main environmental factors which have influenced their community structure.

\section{STUDY AREA}

"Malladas" is the local name of the peridunal ponds in L'Albufera Natural Park (Valencia, Spain).

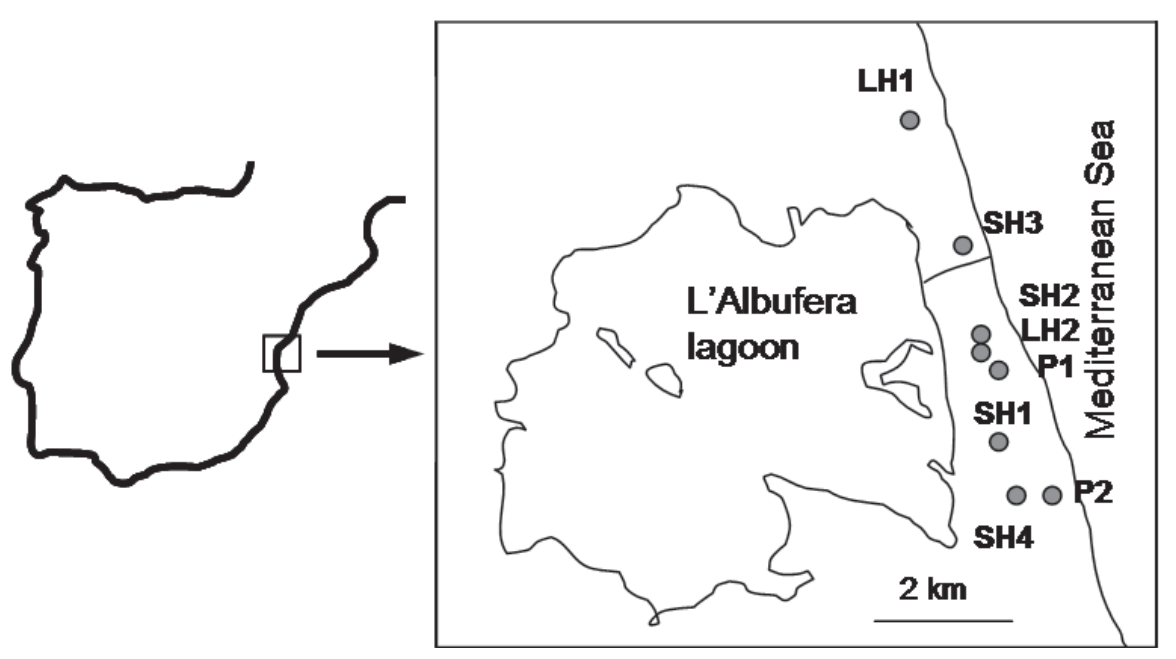

Figure 1. Map of the study site. Mapa del área de estudio. 
They are located in the sandy stretch that separates l'Albufera, a coastal lagoon, from the Mediteranean Sea. They are filled by rain and ground water.

From the 1960s-1970s most of the ponds and wetlands were silted, but since the late 1980s, several restoration projects have been carried out with the aim of restoring the original habitat. Therefore, the remains of the antique ponds were dug to different depths, to create both temporary and permanent ponds.

A set of eight ponds (Fig. 1) was selected for this study: two permanent and six temporary ones, showing differences in hydroperiod duration. The ponds were quite close, the longest distance among them is eight $\mathrm{km}$ (between LH1 and P2). The permanent systems (P1 and P2) have a dense bed of macrophytes in their central areas. They house small fish as Gambusia holbrooki and the endemic Aphanius iberus (pers. obs.) and amphibians (Rana perezi). The pond P1 was specifically restored to be used as a refuge for A. iberus, an endangered species. The temporary ponds are fishless systems, but house amphibian populations. In this set of temporary ponds, two of them had water more than 7 months in the studied period, they were labelled as long hydroperiod (LH1 and LH2), and 4 ponds with shorter hydroperiod $(\mathrm{SH})$ had water less than 6 months in the same period. The ponds differed also in the year of restoration: some of them (P2, LH1, SH1, and SH4) were totally restored in the 1990s; and others (P1, LH2, SH2 and SH3) were restored between 2003 and 2004. P1 and SH3 were never completely desiccated and silted, but through the restoration process their depth and water surface increased.

The basic limnological characteristics of some of the ponds were studied in the 1980s, before the restoration project (Soria \& Alfonso, 1993; Alfonso, 1996), and recently only a study on large crustaceans (Rueda Sevilla et al., 2006) has been done.

\section{METHODS}

The study period started in autumn, when the ponds were filled by rainfall (November 2006). Ponds were sampled fortnightly until they dried out (or contained less than $5 \mathrm{~cm}$ water). For the permanent ones, sampling finished in July 2007.

Several variables were measured in situ: conductivity, temperature, $\mathrm{pH}$, dissolved oxygen and maximum depth. One liter water sample was taken at $0.1 \mathrm{~m}$ from the surface and filtered for nutrient and chlorophyll $a$ analysis in the laboratory. Chlorophyll $a$ concentration was determined spectrophotometrically from Whatman GF/F glass fibre filters, after extraction with $90 \%$ acetone, following the method of Jeffrey \& Humphrey (1975). Nitrate and phosphate were measured by colorimetry from filtered samples (Golterman et al., 1978; APHA, 1980; Murphey \& Riley, 1962). For all these procedures a Hitachi U2001 Spectrophotometer was used.

Zooplankton samples were taken by filtering, through a $35 \mu \mathrm{m}$ mesh-size net, a known volume of water taken from different sites in the ponds. We usually filter 101 except when there were many organisms in the water column, then the filtered volumes were smaller (a minimum of 61) to avoid filter clogging. The organisms were stored in $4 \%$ formalin, and identified and counted in the laboratory using an inverted microscope (Olympus CK40). All the organisms in the samples were counted and, when possible, the individuals were identified to species level, according to Koste (1978) for rotifers; Dussart (1967 and 1969) for copepods, and Alonso (1996) for branchiopods. Nauplii, copepodites and other juveniles were assigned to species considering adult species proportions.

Some community structure parameters were calculated: species richness per visit of the three main groups (rotifers, cladocerans and copepods), mean diversity calculated with Shannon-Wiener index, and the evenness. A one-way ANOVA was performed to see the differences in the measures of diversity related with the hydroperiod (in the permanent, the long hydroperiod, and the short hydroperiod ponds) and with the different time of restoration of the ponds (partially restored, restored in the 1990s and recently restored).

For the multivariate analysis, all the environmental variables, except $\mathrm{pH}$, and the species densities were log transformed. Time since restoration was added as a categorical variable in three 
Table 1. Mean values and standard deviation (in brackets) of the environmental variables measured during the study period in the different ponds. P: permanent pond; LH: long hydroperiod pond; SH: short hydroperiod pond; Rest: restoration; 1: partially modified; 2: restored in 90s; 3: restored in 2003-2004. Valor medio y desviación típica (entre paréntesis) de las variables ambientales medidas durante el periodo de estudio en las diferentes charcas. P: charca permanente; LH: charcas de hidroperiodo largo; SH: charcas de hidroperiodo corto; Rest: restauración; 1: parcialmente modificadas; 2: restauradas en los 90; 3: restauradas en 2003-2004.

\begin{tabular}{|c|c|c|c|c|c|c|c|c|c|}
\hline & $\begin{array}{c}\text { Conductivity } \\
\mathrm{mS} / \mathrm{cm}\end{array}$ & $\begin{array}{l}\text { Temperature } \\
{ }^{\circ} \mathrm{C}\end{array}$ & $\mathrm{pH}$ & $\begin{array}{c}\text { Oxygen } \\
\mathrm{mg} / \mathrm{L}\end{array}$ & $\begin{array}{l}\text { Depth } \\
\mathrm{cm}\end{array}$ & $\begin{array}{l}\mathrm{Chl} a \\
\mathrm{mg} / \mathrm{L}\end{array}$ & $\begin{array}{c}\text { Nitrate } \\
\mathrm{mg} / \mathrm{L}\end{array}$ & $\begin{array}{c}\text { Phosphate } \\
\text { mg/L }\end{array}$ & Rest \\
\hline P1 & & 1 & & & & & & .0 & 1 \\
\hline P2 & & & & & & & & & 2 \\
\hline 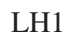 & & & & & & & & & 0 \\
\hline $\mathrm{H} 2$ & 2 & 17.3 & 9.1( & $(+13)$ & 21 & & & 0.03 & 3 \\
\hline H1 & 1.2( & $16.4( \pm$ & $8.6( \pm$ & $8.5( \pm 1.4)$ & 11( & $3(=$ & 4) & 0.06 & 2 \\
\hline quU & $2.0( \pm 0.9)$ & $18.3( \pm 4.0)$ & $9.1( \pm 0$ & $9.7( \pm 0.8$ & $17( \pm 5)$ & $4.14( \pm 3$ & $1.11( \pm 0$. & 0.04 & 3 \\
\hline $\mathrm{H}$ & 6 & 17.4 & & & & 4.8 & 1.0 & 0.12 & \\
\hline $\mathrm{SH} 4$ & $0.8( \pm 0.3)$ & $13.7( \pm 2.7)$ & $8.3( \pm 0.2)$ & $9.0( \pm 1.5)$ & $14( \pm 5)$ & $4.21( \pm 2.78)$ & $1.09( \pm 0.24)$ & $0.03( \pm 0.01)$ & 2 \\
\hline
\end{tabular}

groups: ponds modified; ponds restored in the 1990s and ponds restored recently (between 2003 and 2004). A CCA was carried out using CANO$\mathrm{CO}$ to detect the patterns of variation in the species composition and the main relations between the species and each of the environmental variables. Rare species were downweighted and two Monte Carlo tests (499 permutations) were performed to test the significance of the canonical axes.

\section{RESULTS}

\section{Environmental variables}

Conductivity in the temporary ponds (Table 1) ranged from $0.43 \mathrm{mS} / \mathrm{cm}$ in $\mathrm{SH} 4$ in Decem- ber, to $10.06 \mathrm{mS} / \mathrm{cm}$ in November in SH3. Temporary ponds showed greater temporal variation than permanent ponds. Depth was positively correlated with water permanence $\left(R^{2}=0.78\right.$; $p<0.01)$ and it was higher in the permanent ponds (P1 and P2). The $\mathrm{pH}$ varied from 8.2 to 9.1 and, like the oxygen concentration, which ranged from $9.4 \mathrm{mg} / \mathrm{l}$ (P2) to $11.6 \mathrm{mg} / \mathrm{l}$ (SH3), did not show a high temporal variation. The nutrient concentrations were low, varying between 0.87 and $1.30 \mathrm{mg} / \mathrm{l}$ (nitrate) and between 0.03 and $0.12 \mathrm{mg} / \mathrm{l}$ (phosphate), with a maximum value of phosphate of $0.89 \mathrm{mg} / \mathrm{l}$ in November in SH3. The chlorophyll $a$ concentration was slightly higher in P2 and LH2 (maximum of $50 \mu \mathrm{g} / \mathrm{l}$ ), which had also a higher temporal variation.

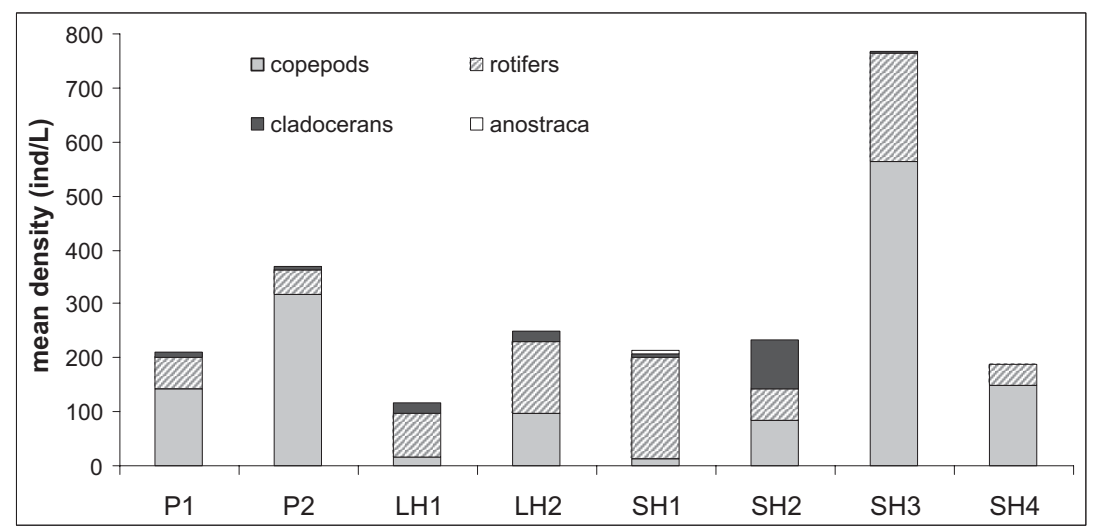

Figure 2. Mean density (ind/l) of the main zooplankton taxa found in each pond: Permanent ponds (P), long hydroperiod ponds (LH) and short hydroperiod ponds (SH). Densidad media (indll) de los principales taxones de zooplancton de cada charca: charcas permanentes $(P)$, con largo hidroperiodo $(\mathrm{LH})$ y con corto hidroperiodo $(\mathrm{SH})$. 
Table 2. List of rotifer, copepod and branchiopod species with an abundance higher than $0.5 \%$ and their presence in the ponds. Other species found with an abundance lower than $0.5 \%$ : Brachionus angularis, B. calyciflorus, B. ibericus, B. quadridentatus brevispinus, B. urceolaris, B. variabilis, Cephalodella $\mathrm{cf}$ cyclops, C. cf intuta, C. gracilis, Cephalodella sp., Collotecha sp., Colurella uncinata, Cupelopagis vorax, Encentrum cf marinum, E. saundersiae, Eosphora ehrenbergi, Euchlanis meneta, Lecane cf abanica, L. aculeata, L. curvicornis, L. decipiens, L. grandis, L. hamata, L. hornemanni, L. inermis, L. inopinata, L. lamellata, L. latissima, L. luna, Lepadella acuminata, L. triptera, Lophocaris salpina, Mytilina ventralis, Notholca acuminata, Platyas quadricornis, Pleurotrocha petromyzon, Proales sp., Ptygura sp., P. cf longicornis, Squatinella rostrum, Testudinella patina, Trichocerca rattus, T. weberi, Trichocerca sp., Tripleuchlanis sp., Horsiella brevicornis, adult Calanoida, adult Harpacticoida, Alona rustica, Pleuroxus aduncus, Daphnia pulicaria, Macrothrix laticornis, Megafenestra aurita, Moina sp., Scapholeberis ramneri and Simocephalus vetulus. Listado de especies de rotíferos, copépodos y branquiópodos con una abundancia mayor de $0.5 \%$ y su presencia en las diferentes charcas. Otras especies encontradas con una abundancia menor a $0.5 \%$ fueron: Brachionus angularis, B. calyciflorus, B. ibericus, B. quadridentatus brevispinus, B. urceolaris, B. variabilis, Cephalodella $c f$ cyclops, C. $c f$ intuta, C. gracilis, Cephalodella $s p$., Collotecha $s p$., Colurella uncinata, Cupelopagis vorax, Encentrum $c f$ marinum, E. saundersiae, Eosphora ehrenbergi, Euchlanis meneta, Lecane cf abanica, L. aculeata, L. curvicornis, L. decipiens, L. grandis, L. hamata, L. hornemanni, L. inermis, L. inopinata, L. lamellata, L. latissima, L. luna, Lepadella acuminata, L. triptera, Lophocaris salpina, Mytilina ventralis, Notholca acuminata, Platyas quadricornis, Pleurotrocha petromyzon, Proales sp., Ptygura sp., P. $c f$ longicornis, Squatinella rostrum, Testudinella patina, Trichocerca rattus, T. weberi, Trichocerca sp., Tripleuchlanis sp., Horsiella brevicornis, adult Calanoida, adult Harpacticoida, Alona rustica, Pleuroxus aduncus, Daphnia pulicaria, Macrothrix laticornis, Megafenestra aurita, Moina sp., Scapholeberis ramneri y Simocephalus vetulus.

\begin{tabular}{|c|c|c|c|c|c|c|c|c|}
\hline & P1 & $\mathbf{P 2}$ & LH1 & LH2 & SH1 & SH2 & SH3 & $\overline{\text { SH4 }}$ \\
\hline \multicolumn{9}{|l|}{ ROTIFERA } \\
\hline Anuraeopsis fissa (Gosse, 1851) & 0.6 & 0.3 & 0.1 & 0.1 & & & & 0.1 \\
\hline Bdelloidea & 0.7 & 1.6 & 0.3 & 0.7 & 0.9 & 5.2 & 0.1 & 0.1 \\
\hline Brachionus plicatilis (Müller, 1786) & 0.2 & 1.7 & 0.3 & 0.1 & & & 4.5 & \\
\hline Cephalodella catellina (Müller, 1786) & 0.0 & & & 1.3 & 0.0 & 0.4 & 0.1 & 0.1 \\
\hline Cephalodella gibba (Ehrenberg, 1832) & 0.1 & 0.1 & 0.4 & & 0.3 & 0.3 & & 3.6 \\
\hline Colurella adriatica (Ehrenberg, 1831) & 0.5 & 0.2 & 0.1 & 0.1 & & & 0.1 & \\
\hline Colurella colurus (Ehrenberg, 1830) & & & 0.1 & 0.1 & 0.1 & 0.5 & 0.1 & 0.7 \\
\hline Eosphora najas (Ehrenberg, 1830) & 0.7 & & & & & & & \\
\hline Hexarthra fennica (Levander, 1892) & & 0.1 & 11.4 & 26.4 & 77.6 & 11.1 & 4.8 & 0.1 \\
\hline Hexarthra oxyuris (Sernov, 1903) & 4.0 & & & & & & & \\
\hline Keratella tropica (Apstein, 1907) & 1.1 & & 0.2 & 0.1 & 0.1 & 0.1 & 7.5 & 0.1 \\
\hline Lecane bulla (Gosse, 1851) & 0.5 & 0.1 & 0.3 & 0.1 & & & & \\
\hline Lecane closterocerca (Schmarda, 1859) & 0.2 & 1.8 & 0.4 & & & & & 0.1 \\
\hline Lecane furcata (Murray, 1913) & 1.5 & & 0.3 & & & & & \\
\hline Lecane nana (Murray, 1913) & 0.1 & 0.1 & & & 0.1 & 0.2 & & 1.5 \\
\hline Lecane punctata (Murray, 1913) & 5.7 & 0.9 & & & & & & \\
\hline Lecane pyriformis (Daday, 1905) & 0.1 & 0.1 & 0.1 & & & & & 0.6 \\
\hline Lecane quadridentata (Ehrenberg, 1832) & 2.5 & & & & & & & \\
\hline Lepadella patella (Müller, 1786) & 0.2 & 0.3 & 6.8 & 0.1 & 0.1 & 2.4 & & 2.0 \\
\hline Lindia torulosa (Dujardin, 1841) & 0.1 & & & 0.1 & 0.8 & 1.5 & 0.1 & 0.1 \\
\hline Notholca squamula (Müller, 1786) & 0.1 & 0.2 & 0.1 & & 0.5 & & 0.1 & 0.1 \\
\hline Polyarthra dolichoptera (Idelson, 1925) & 11.3 & 2.8 & 29.4 & 0.1 & & & 0.1 & 0.1 \\
\hline Synchaeta oblonga (Ehrenberg, 1832) & 0.1 & 0.5 & 5.5 & & & & & \\
\hline Synchaeta pectinata (Ehrenberg, 1832) & 3.4 & & 0.1 & & & & & \\
\hline Trichocerca cf elongata (Gosse, 1886) & 0.1 & & 0.7 & 0.1 & & & & \\
\hline Trichocerca pusilla (Lauterborn, 1898) & 0.1 & 0.5 & & & & & & 0.1 \\
\hline \multicolumn{9}{|l|}{ COPEPODA } \\
\hline Tropocyclops prasinus (Fischer, 1860) & 34.2 & & & 0.6 & & & & 3.9 \\
\hline Acanthocyclops americanus (Marsh, 1892) & 21.1 & 86.0 & & 56.2 & 0.4 & 34.0 & 26.6 & 0.2 \\
\hline Eucyclops serrulatus (Fischer, 1851) & 3.0 & & & 0.9 & 6.2 & & & \\
\hline Eucyclops speratus (Lilljeborg, 1901) & & & 2.2 & & & 8.0 & & \\
\hline Diacyclops bisetosus (Rehberg, 1880) & & & 15.0 & 9.1 & & 4.5 & 55.2 & 6.0 \\
\hline Diacyclops bicuspidatus (Claus, 1857) & & & 4.4 & & 0.4 & & 0.1 & 80.6 \\
\hline Metacyclops minutus (Claus, 1863) & & & 6.7 & & 0.4 & & & \\
\hline cf Speocyclops & & & & & 2.9 & & & \\
\hline
\end{tabular}


Table 2. (cont.)

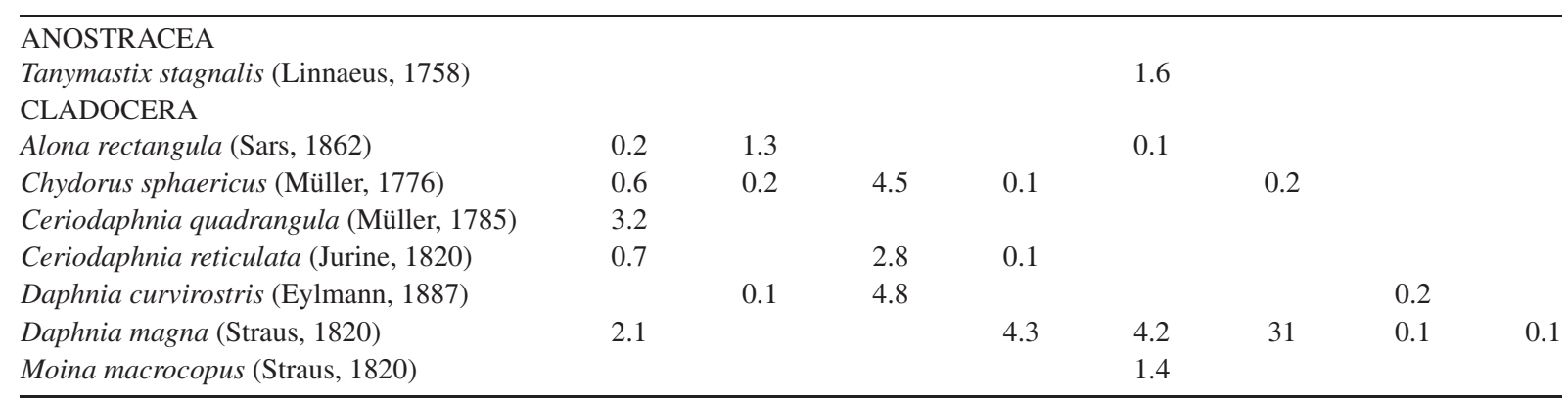

\section{Zooplankton community structure}

Across the study a total of 100 species were found: 71 rotifers, 15 cladocerans, 13 copepods and one anostracan. In the permanent ponds a higher number of species appeared (Tables 2 and 3). The most common species were bdelloid rotifers which were present in all studied ponds and Acanthocyclops americanus, Hexarthra fennica, Keratella tropica and Lepadella patella which were recorded in seven of the eight ponds.

The highest average zooplankton density (Fig. 2) was found in SH3, (767.8 ind/l), and the lowest in LH1 (116.8 ind/l) (Fig. 2). The dominant group varied among the ponds: in the permanent ponds (P1 and P2), and two of the short period temporary ones ( $\mathrm{SH} 3$ and $\mathrm{SH} 4$ ), the copepods (mainly larval and juvenile stages) dominated. The short hydroperiod pond $\mathrm{SH} 2$ was the only one dominated by cladocerans (Daphnia magna). Rotifers were the most abundant group in the rest of the ponds: planktonic species, such as Polyarthra dolichoptera and H. fennica, were dominant. The only anostracan species found, Tanymastix stagnalis, occurred in SH1 with a mean density of $6.2 \mathrm{ind} / \mathrm{l}$, mostly in the juvenile stage.

Rotifers were the group with the highest number of species in all the ponds, with a maximum value of 47 species in $\mathrm{P} 1$, and a minimum of 12 species in SH1. Overall, between three and six copepod species were recorded per pond, while for the cladocerans, between three (temporary ponds) and 11 species (permanent pond, P1) were encountered.

The highest copepod, rotifer and total richness per visit was obtained in P1 (Table 3), which also showed a wide range of variation (represented by the high standard deviation). The highest cladoceran richness was found in LH1. In the group of ponds with short hydroperiod, $\mathrm{SH} 4$ had the highest copepod, rotifer and total richness. Diversity calculated with the ShannonWiener index ranged from 0.7 bits ind $^{-1}$ (SH3) to

Table 3. Values of species richness per visit of the main groups of zooplankton, mean diversity (calculated using Shannon-Wiener index) and mean evenness in the ponds. Valores de riqueza por visita de los principales grupos zooplanctónicos, diversidad promedio (calculada usando el índice de Shannon-Wiener) y equitatividad promedio en las lagunas.

\begin{tabular}{|c|c|c|c|c|c|}
\hline \multirow[t]{2}{*}{ Pond } & \multicolumn{3}{|c|}{ Species richness per visit } & \multirow{2}{*}{$\begin{array}{c}\text { Mean Diversity } \\
\quad \text { (bits ind }^{-1} \text { ) }\end{array}$} & \multirow[t]{2}{*}{ Evenness } \\
\hline & cladocerans & copepods & rotifers & & \\
\hline $\mathrm{P} 1$ & $2.7( \pm 1.3)$ & $2.1( \pm 0.8)$ & $11.9( \pm 5.6)$ & $1.3( \pm 0.4)$ & $0.3( \pm 0.1)$ \\
\hline $\mathrm{P} 2$ & $0.4( \pm 0.6)$ & $0.6( \pm 0.6)$ & $11.4( \pm 4.8)$ & $1.0( \pm 0.6)$ & $0.3( \pm 0.2)$ \\
\hline LH1 & $3.5( \pm 0.9)$ & $1.2( \pm 0.8)$ & $10.2( \pm 3.2)$ & $1.4( \pm 0.6)$ & $0.3( \pm 0.3)$ \\
\hline LH2 & $1.4( \pm 0.8)$ & $1.3( \pm 0.8)$ & $4.0( \pm 1.9)$ & $0.8( \pm 0.4)$ & $0.4( \pm 0.2)$ \\
\hline SH1 & $0.7( \pm 1.1)$ & $1.3( \pm 1.0)$ & $5.9( \pm 2.6)$ & $1.3( \pm 0.7)$ & $0.5( \pm 0.2)$ \\
\hline $\mathrm{SH} 2$ & $0.9( \pm 0.6)$ & $0.8( \pm 0.9)$ & $5.5( \pm 2.3)$ & $1.0( \pm 0.3)$ & $0.4( \pm 0.1)$ \\
\hline SH3 & $0.9( \pm 0.6)$ & $1.0( \pm 0.7)$ & $5.4( \pm 1.9)$ & $0.7( \pm 0.4)$ & $0.3( \pm 0.1)$ \\
\hline SH4 & $0.7( \pm 0.8)$ & $2.0( \pm 0.6)$ & $9.7( \pm 1.2)$ & $1.0( \pm 0.6)$ & $0.3( \pm 0.2)$ \\
\hline
\end{tabular}


1.4 bits ind $^{-1}$ (LH1). Evenness was low and quite homogeneous ranging from 0.3 to 0.5 .

The results of the ANOVA showed significant differences in the species richness between the permanent and the temporary ponds $(p<0.05$ between permanent and long hydroperiod ponds; and $p<0.01$ between permanent and short hydroperiod ponds) and it was higher in the permanent ponds. To reduce the effect of the different sampling effort in the permanent and the temporary ponds, only the dates when all the ponds were filled were compared. The differences in the species richness remained significant. With regard to the differences in the time since restoration, the species richness in the ponds recently restored was significantly lower than in the other two groups ( $p<0.01$ in both analysis), also if only the dates when all the ponds had water were compared ( $p<0.05$ between modified and recently restored ponds, and $p<0.01$ between restored in the $90 \mathrm{~s}$ and recently restored).

\section{Relationships between zooplankton and environmental variables}

A total of six environmental variables (depth, conductivity, time since restoration, chlorophyll $a$ and oxygen) as well as 25 zooplankton species were retained to perform the CCA. The first two axes extracted from the CCA accounted for $19 \%$ of variance $(10.2 \%$ of variance the first axis and $8.8 \%$ the second one) and both Monte Carlo tests were significant $(p<0.01)$. The first axis (Fig. 3a) was highly correlated with depth, and separated the deeper and permanent ponds from most of the temporary (shallower) ones. The second axis showed higher correlation with conductivity, chlorophyll $a$ and oxygen; thus in the positive region of this axis were located the systems with higher values of these variables, in particular conductivity and chlorophyll $a$ (SH3, $\mathrm{P} 2$ and LH2).

The species distribution agrees with this ordination (Fig. 3b); a group of species tolerant to higher salinity levels, including A. americanus, Brachionus plicatilis or C. adriatica; appeared in the positive region of the second axis where the ponds with higher conductivity were distributed. The species associated with the permanent
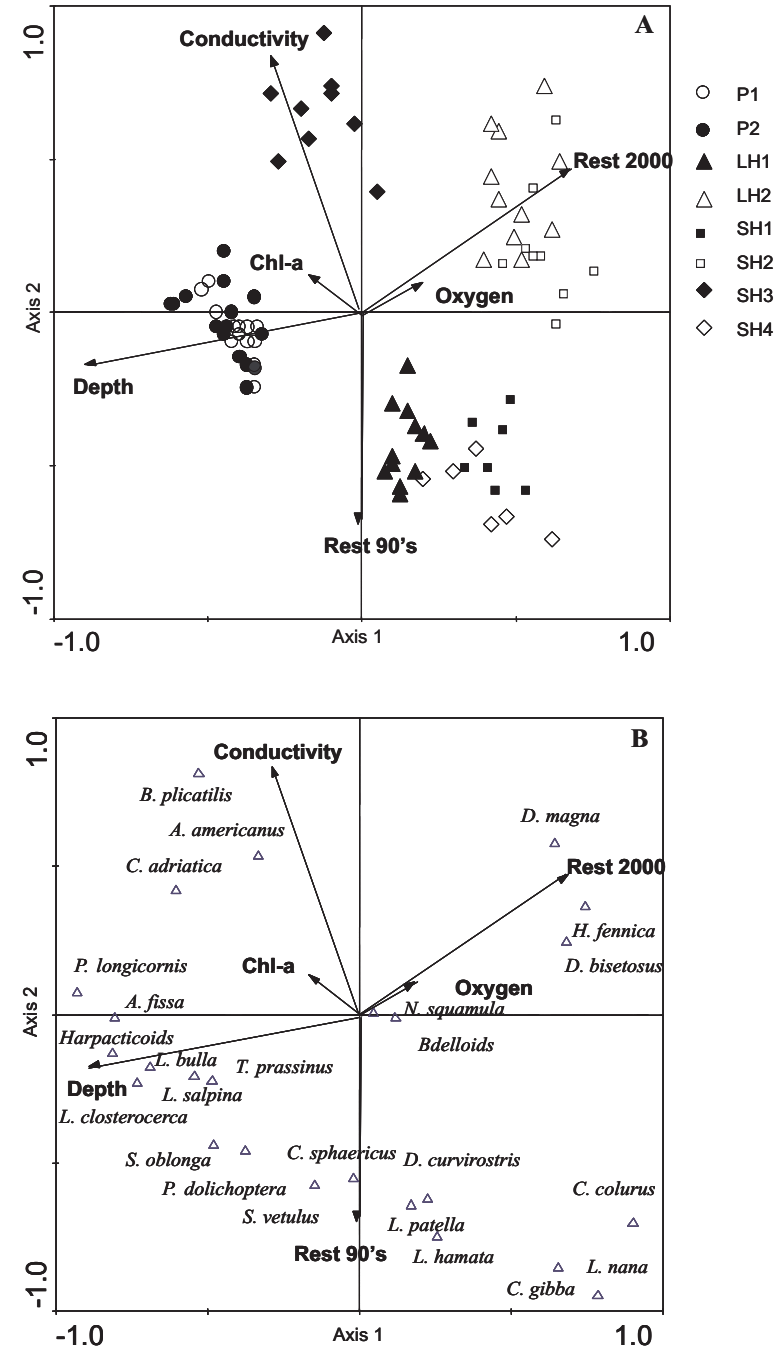

Figure 3. CCA ordination diagram showing the distribution of samples (3a, upper graph) and species position (3b, lower graph) in relation to environmental variables in the space represented by the two first axes. Diagrama de ordenación del CCA mostrando la distribución de las muestras (3a, gráfica superior) y la posición de las especies (3b, gráfica inferior) en relación con las variables ambientales en el espacio representado por los dos primeros ejes.

ponds (negative part of the first axis), are not only characteristic of open waters (such as the rotifers $P$. dolichoptera, Anuraeopsis fissa and Synchaeta oblonga or the copepod T. prasinus) but are also species associated to macrophytes (such as the rotifers Lophocaris salpina and L. bulla or the cladoceran $S$. vetulus). Taxa that appeared in most of the lakes (such as bdelloid roti- 
fers or $N$. squamula) appeared in the centre of the figure. Several littoral species (such as the rotifers $L$. patella, L. nana, C. colurus or the cladocerans $D$. curvirostris and $C$. sphaericus) were found associated with the shallowest ponds with the shortest hydroperiods.

\section{DISCUSSION}

This studied group of peridunal ponds, all located in the same area (maximum distance among them is less than $8 \mathrm{~km}$ ), share some basic characteristics in terms of climate and substrate. Nevertheless, a marked temporal and spatial heterogeneity was found, particularly for limnological variables such as conductivity, trophic level and duration of the inundation period. Thus, we have found a wide range of variation in the ponds which favours the diversity of zooplankton species. Some ponds were restored at different time, although this is not clear in the limnological variables, it seems to have a notorious effect on zooplankton community.

Values of specific richness per visit, diversity and evenness are low, compared with other studies in similar ecosystems (e.g. Galindo et al., 1994; Armengol \& Miracle, 1999; Rodrigo et al., 2001). This could be related with the restoration and subsequent colonization process. Rotifers contributed greatly to the community structure in these ponds. Although this group has been often neglected in zooplankton studies, they were the most diverse group and the most abundant in some ponds. This was also the case in most studies in similar dune ponds, such as the ones carried out by Galindo et al. (1994), Fahd et al. (2000) and Serrano \& Fahd (2005). With regard to the crustaceans, it is remarkable the presence of the anostracean $T$. stagnalis. It was found in only one of the systems, a temporary pond with short hydroperiod (SH1). This large species can outcompete filter feeder cladocerans and rotifers, but it is very sensitive to predation (Bohonak \& Whiteman, 1999). Thus, living in temporary ponds, where larger predators are frequently absent (Schneider \& Frost, 1996), can reduce their risk of predation.
The results of CCA suggest the relevance of conductivity and depth, but they have also indicated the importance that the restoration processes could have on these communities. Nevertheless these results should be taken with caution, due to the low number of ponds studied. The results obtained agree with other studies, where the duration of the hydroperiod (here closely related to depth) could be the main factor determining the structure and composition of the community in aquatic systems (e.g. Wellborn et al., 1996; Boix et al., 2001; Eitam et al., 2004). Generally, the species richness is higher in permanent ponds (e.g. Collison et al., 1995; Alonso, 1998; Spencer et al., 1999) or in the temporary ponds with longer hydroperiods (e.g. Boix et al., 2001; Fahd et al., 2000). The comparison between permanent and temporary water bodies is difficult. Obviously the sampling effort (a longer sampling period in permanent ponds) would increase the cumulative specific richness. Nevertheless, as stated previously, significant differences are still found when only the period with water in all the ponds was compared.

In this study, permanent ponds recorded the highest number of species which is probably related to several factors: (i) greater habitat heterogeneity, due to the abundance of macrophytes and to the greater depth of these ponds (Crosetti \& Margaritora, 1987), (ii) more time to complete life cycles, community development and colonization, (iii) larger diversity of conditions which could enable the hatching of more species diapausing eggs (iv) abundance of waterfowl, an important vector for the dispersal of zooplankton in resting stages (e.g. Figuerola \& Green, 2002), and finally, (v) permanent ponds harbour fish populations and more macroinvertebrate predators (dragonflies, damselflies, water beetles, etc.), so they have stronger predation pressure, preventing the dominance of a few species (Spencer et $a l ., 1999)$. This can also affect positively smallsized zooplankton species (rotifers and juvenile copepods), which can better support the predatory pressure of fish (Herzig, 1994), and are inferior competitors to large-sized species (e.g. Gilbert, 1988; MacIsaac \& Gilbert, 1991). Following hydroperiod-depth, conductivity seems to 
be the second factor affecting the zooplankton community. The role of salinity in influencing the community structure in ponds has been largely studied (Williams, 1999; Brock et al., 2005; Toumi et al., 2005; Waterkeyn et al., 2008). In this study, salinity ( conductivity) negatively affected the species richness, in accordance to other studies (e.g. Boronat et al., 2001; Frisch et al., 2006; Martinoy et al., 2006; Waterkeyn et al., 2008).

In our study, the time since the ponds were restored is also a very important factor to explain the ordination of samples. Badosa et al. (2006) found a lower biodiversity in old lagoons. In general terms, the opposite was found, because the ponds which were restored recently had lower species richness. The restoration is very important in terms of community succession and colonization processes, since older ponds frequently have dense egg banks and, therefore greater opportunities for hatching.

In conclusion, in our study ponds, the depth, highly related with the permanence of water, had a positive effect on the diversity of aquatic organisms, especially in the permanent ponds, where the highest number of zooplankton species was recorded, particularly of rotifers. Other factors, such as salinity and the time since the ponds were restored, which involve processes such as the tolerance to high salinity levels or the dispersal and colonization processes, also help to better explain the community structure of these peridunal ponds. The results obtained here highlighted the importance of the restoration processes to recover the biodiversity of aquatic systems, particularly in places heavily affected by human activities.

\section{ACKNOWLEDGEMENTS}

We want to thank Andreu Escrivà, Carla Olmos, Yasmin Gomez and Laia Zamora for assistance in the field and in the laboratory, as well as the Oficina Técnica de la Devesa-Albufera and Generalitat Valenciana. Deirdre Flanagan and Aline Waterkeyn helped to improve the manuscript with language correction and valuable comments. Financial support for this research was partly provided by a predoctoral grant and the project
CGL2008-03760 from the Ministerio de Ciencia e Innovación of the Spanish Government.

\section{REFERENCES}

ALFONSO, M. T. 1996. Estudio de las comunidades zooplanctónicas de los ecosistemas acuáticos del Parque natural de La Albufera de Valencia. Tesis doctoral, Universidad de Valencia. 439 pp.

ALONSO, M. 1996. Crustacea. Branquiopoda. Fauna Ibérica. Vol 7. Museo Nacional de Ciencias Naturales, C S I C. Madrid. 486 pp.

ALONSO, M. 1998. Las lagunas de la España peninsular. Limnetica, 15: 1-176.

APHA. 1980. Standard methods for the examination of water and wastewater. Washington D.C.: American Public Health Association. 1268 pp.

ARMENGOL, X. \& M. R. MIRACLE. 1999. Zooplankton communities in doline lakes and pools in relation to some bathymetric parameters and physical and chemical variables. J. Plankton Res., 21: 2245-2261.

BADOSA, A., D. BOIX, S. BRUCET, R. LÓPEZFLORES \& X. D. QUINTANA. 2006. Nutrients and zooplankton composition and dynamics in relation to the hydrological pattern in a confined Mediterranean salt marsh (NE Iberian Peninsula). Estuar. Coast. Shelf Sci., 66: 513-522.

BADOSA, R. LÓPEZ FLORES \& X. D. QUINTANA. 2007. Comparative biodiversity of crustaceans and aquatic insects from various water body types in coastal Mediterranean wetlands. Hydrobiologia, 584: 347-359.

BEKLIOGLU, M., S. ROMO, I. KAGALOU, X. QUINTANA \& E. BÉCARES. 2007. State of the art in the functioning of shallow Mediterranean lakes: workshop conclusions. Hydrobiologia, 584: 317-326.

BOHONAK, A. J. \& H. H. WHITEMAN. 1999. Dispersal of the fairy shrimp Branchinecta coloradensis (Anostraca): Effects of hydroperiod and salamanders. Limnol. Oceanogr., 44: 487-493.

BOIX, D., J. SALA \& R. MORENO-AMICH. 2001. The faunal composition of Espolla Ponds (NE Iberian Peninsula): The neglected biodiversity of temporary waters. Wetlands, 21: 577-592.

BOIX, D., J. SALA, S. GASCÓN, M. MARTINOY, J. GIFRE, S. BRUCET, A., BADOSA, R., LÓPEZ FLORES, R. \& X. D. QUINTANA. 2007. Comparative biodiversity of crustaceans and aquatic insects 
from various waterbody types in Coastal Mediterranean wetlands. Hidrobiologia, 548: 347-359.

BORONAT, L., M. R. MIRACLE \& X. ARMENGOL. 2001. Cladoceran assemblages in a mineralization gradient. Hydrobiologia, 442: 75-88.

BROCK, M. \& D. L. NIELSEN. 2005. Changes in biotic communities developing from freshwater wetland sediments under experimental salinity and water regimes. Freshwat. Biol., 50: 1376-1390.

CÉRÉGHINO, R., J. BIGGS, B. OERTLI \& S. DECLERCK. 2008. The ecology of European ponds: defining the characteristics of a neglected freshwater habitat. Hydrobiologia, 597: 1-6.

COLLISON, N. H., J. BIGGS, A. CORFIELD, M. J. HODSON, D. WALKER, M. WHITFIELD \& P. J. WILLIAMS. 1995. Temporary and permanent ponds: an assessment of the effects of drying out on the conservation value of aquatic macroinvertebrate communities. Biol. Conserv., 74: 125-133.

M. CROSETTI, D. \& F. G. MARGARITORA. 1987. Distribution and life cycles of cladocerans in temporary pools from Central Italy. Freshwat. Biol., 18: 165-175.

DUSSART, B. 1967. Les copépodes des eaux continentales d'Europe occidentale. Tome I: Calanoïdes et Hapacticoïdes. Boubee \& Cie. Paris. 500 pp.

DUSSART, B. 1969. Les copépodes des eaux continentales d'Europe occidentale. Tome II: Cyclopoïdes et Biologie. Boubee \& Cie. Paris. 292 pp.

EITAM, A., L. BLAUSTEIN, K. VAN DAMME, H. J. DUMONT \& K. MARTENS. 2004. Crustacean species richness in temporary pools: relationships with habitat traits. Hydrobiologia, 525: 125-130.

FAHD, K., L. SERRANO \& J. TOJA. 2000. Crustacean and rotifer composition of temporary ponds in the Doñana National Park (SW Spain) during floods. Hydrobiologia, 436: 41-49.

FIGUEROLA, J. \& A. J. GREEN. 2002. Dispersal of aquatic organisms by waterbirds: a review of past research and priorities for future studies. Freshwat. Biol., 47: 483-494.

FRISCH, D., E. MORENO-OSTOS \& A. J. GREEN. 2006. Species richness and distribution of copepods and cladocerans and their relation to hydroperiod and other environmental variables in Doñana, South-west Spain. Hydrobiologia, 556: 327-340.

GALINDO, M. D., A. J. MATA, N. MAZUELOS \& L. SERRANO. 1994. Microcrustacean and rotifer diversity and richness relating to water temporality in dune ponds of the Doñana National Park (SW Spain). Verh. Internat. Verein. Limnol., 25: 1350-1356.
GILBERT, J. J. 1988. Suppression of rotifer populations by Daphnia: A review of the evidence, the mechanisms, and the effects on zooplankton community structure. Limnol. Oceanogr., 33: 1286-1303.

GOLTERMAN, H. L., R. S. CLYMO \& M. OHNSTAD. 1978. Methods for physical and chemical analysis of freshwaters. IBP Handbook 8. Blackwell, Oxford UK. 213 pp.

GREEN, A. J., C. FUENTES, E. MORENO-OSTOS \& S. L. RODRIGUES DA SILVA. 2005. Factors influencing cladoceran abundance and species richness in brackish lakes in Eastern Spain. Annal. Limnol.-Int. J. Lim., 41: 73-81.

HERZIG, A. 1994. Predator-prey relationships within the pelagic community of Neusiedler See. $H y$ drobiologia, 275/276: 81-96.

JEFFREY,E. \& G. F. HUMPHREY. 1975. New spectrophotometric equations for determining chlorophylls $a, b, c 1$ and $c 2$ in higher plants, algae and natural phytoplankton. Biochem. Physiol. Pflanzen, 167: 91-194.

KOSTE, W. 1978. Rotatoria. Die rädertiere Mitteleuropas. Monogonta. Gerbrüder Bortraeger. Berlin. 663 pp.

LÓPEZ, T., J. TOJA \& N. A. GABELLONE. 1991. Limnological comparison of two peridunal ponds in the Doñana National Park (Spain). Arch. Hydrobiol., 120: 357-378.

MARTINOY M., D. BOIX, J. SALA, S. GASCÓN, J. GIFRE, A. ALGERICH, R. DE LA BARRERA, S. BRUCET, A. BADOSA, R. LÓPEZ-FLORES, M. MÉNDEZ, J. M. UTGÉ \& X. D. QUINTANA. 2006. Crustacean and aquatic insect assemblages in the Mediterranean coastal ecosystems of Empordà wetlands (NE Iberian peninsula). Limnetica, 25: 665-682.

MAZUELOS, N., J. TOJA \& C. GUISANDE. 1993. Rotifers in ephemeral ponds of Doñana National Park. Hydrobiologia, 255/256: 429-434.

MacISAAC, H. J. \& J. J. GILBERT. 1991. Discrimination between exploitative and interference competition between Cladocera and Keratella cochlearis. Ecology, 72: 924-937.

MURPHEY, J. \& J. A. RILEY. 1962. A modified single-solution method for the determination of phosphate in natural waters. Anal. Chim. Acta, 27: 31-36.

OERTLI, B., D. A. JOYE, E. CASTELLA, R. JUGE, D. CAMBIN \& J. B. LACHAVANNE. 2002. Does size matter? The relationship between pond area and biodiversity. Biol. Conserv., 104: 59-70. 
ORTEGA-MAYAGOITIA, E., C. ROJO \& X. ARMENGOL, 2000. Structure and dynamics of zooplankton in a semi-arid wetland, the National Park de Daimiel (Spain). Wetlands, 24: 629-638.

QUINTANA, X. D., D. BOIX, A. BADOSA, S. BRUCET, J. COMPTE, S. GASCÓN, R. LÓPEZFLORES, J. SALA \& R. MORENO-AMICH. 2006. Community structure in Mediterranean shallow lentic ecosystems: size-based vs. taxon-based approaches. Limnetica, 25 (1-2): 303-320.

RUEDA-SEVILLA, J., J. A. AGUILAR-ALBEROLA \& F. MEZQUITA-JUANES. 2006. Contribución al conocimiento de los crustáceos (Arthropoda, Crustacea) de las Malladas de la Devesa del Parque Natural de la Albufera (Valencia). Bol. Asoc. Esp. Entomol., 30: 9-29.

SCHNEIDER, D. W. \& T. M. FROST. 1996. Habitat duration and community structure in temporary ponds. J. N. Am. Benthol. Soc., 15: 64-86.

SERRANO, L. \& K. FAHD. 2005. Zooplankton communities across a hydroperiod gradient of temporary ponds in the Doñana National Park (SW Spain). Wetlands, 25: 101-111.

SORIA, J. M. \& M. T. ALFONSO. 1993. Relations between physico-chemical and biological characteristics in some coastal intradune ponds near Valencia (Spain). Verh. Internat. Verein. Limnol., 25: 1009-1013.

SPENCER, M., L. BLAUSTEIN, S. S. SCHWARTZ
\& J. E. COHEN. 1999. Species richness and the proportion of predatory animal species in temporary freshwater pools: relationships with habitat size and permanence. Ecol. Lett., 2: 157-166.

TOUMI, N., H. AYADI, O. ABID, J. F. CARRIAS, T. SIME-NGANDO, M. BOUKHRIS \& A. BOUAIN. 2005. Zooplanckton distribution in four ponds of different salinity: a seasonal study in the solar solterns of Sfax (Tunisia). Hidrobiologia, 53: 1-9.

WATERKEYN, A., P. GRILLAS, B. VANSCHOENWINKEL \& L. BRENDONCK. 2008. Invertebrate community patterns in Mediterranean temporary wetlands a long hydroperiod and salinity gradients. Freshwat. Biol., 53(9): 1808-1822.

WELLBORN, G. A., D. K. SKELLY \& E. E. WERNER. 1996. Mechanisms creating community structure across a freshwater habitat gradient. Ann. Rev. Ecol. Syst., 27: 337-363.

WHITFIELD, M. \& P. J. WILLIAMS. 1995. Temporary and permanent ponds: an assessment of the effects of drying out on the conservation value of aquatic macroinvertebrate communities. Biol. Conserv., 74: 125-133.

WILLIAMS, W. D. 1999. Salinisation: Amajor threat to water resources in the arid and semi-arid regions of the world. Lakes Reserv.: Res. Manage., 4: 85-91.

WILLIAMS, D. D. 2006. The biology of temporary waters. Oxford: Oxford University Press. 348 pp. 